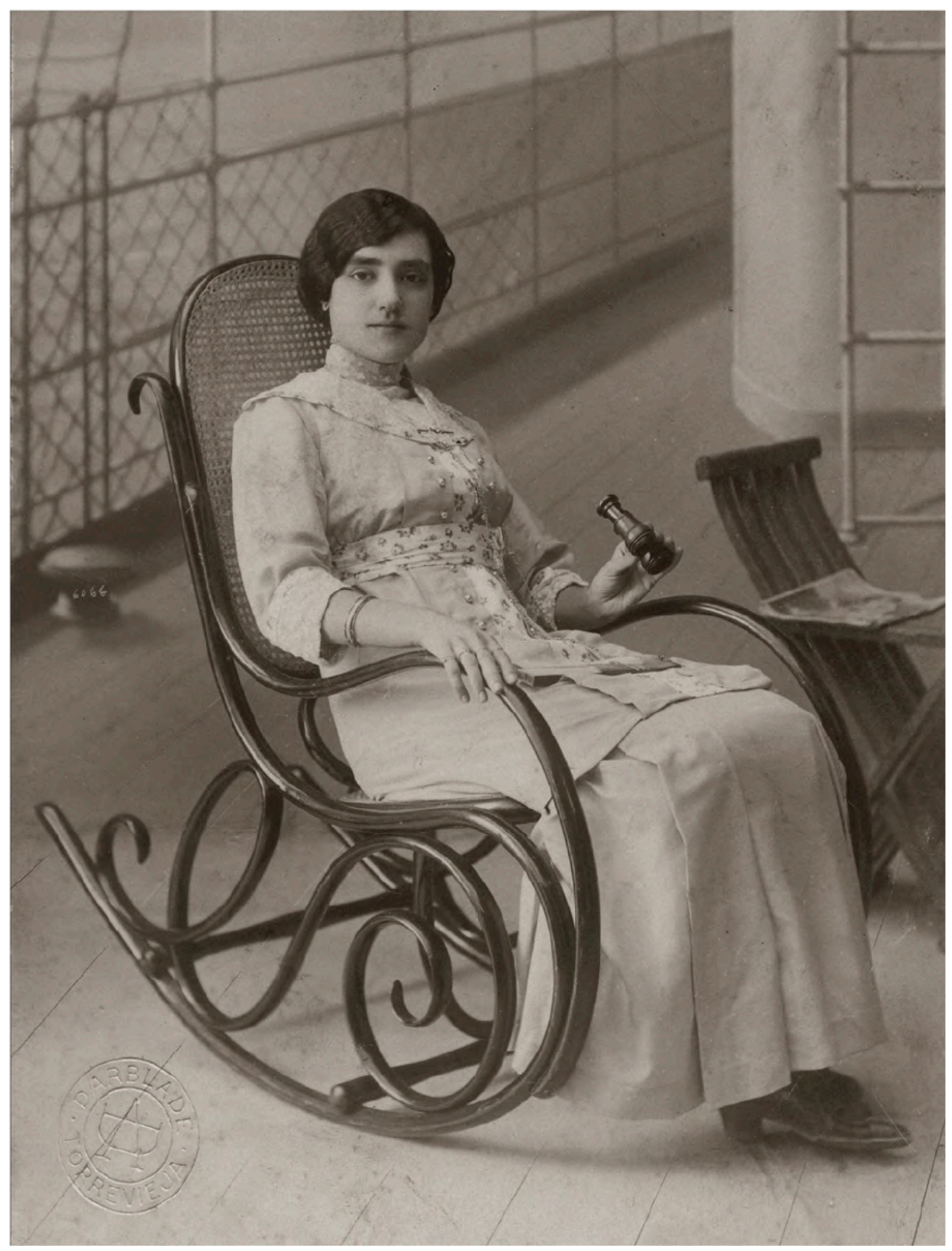

Retrato. Fotografía: Jean Darblade 


\section{EL ESPAI CORBAT DE LA FUNDACIÓ CAIXA VINARÒS. UN CENTRO DE DIVULGACIÓN DEL MUEBLE CURVADO}

\section{THE ESPAI CORBAT OF THE FUNDACIÓ CAIXA VINARÒS. A CENTER FOR THE DISSEMINATION OF BENTWOOD FURNITURE}

\section{Julio Vives Chillida \\ Director del Espai corbat de la Fundació Caixa Vinaròs}

Resumen El artículo presenta una experiencia cultural impulsada desde la Fundació Caixa Vinaròs sobre la exposición de una colección de mueble curvado valenciano, en particular mecedoras, pero también de mueble curvado vienés: el Espai corbat. En el texto se explican e ilustran los orígenes, las características, también desde la perspectiva del patrimonio cultural, y el contenido de este espacio, incluidos sus aspectos didácticos. El Espai corbat ha contribuido a lo largo de sus diez años de funcionamiento a la difusión del patrimonio cultural constituido por el mueble curvado, especialmente del valenciano. Lo ha hecho no solo mediante la sede física en la Fundación, sino también a través de la promoción de diversas exposiciones en las que la colección de mobiliario ha estado representada.

Palabras clave

Abstract

Keywords
Espai corbat, exposición, Fundació Caixa Vinaròs, mecedora, mueble curvado.

This article presents a cultural experience promoted by the Fundació Caixa Vinaròs at an exhibition of a collection of Valencian bentwood furniture, particularly rocking chairs, but also Viennese furniture -the Espai corbat-. This text explain and illustrates the origins, characteristics -also from the perspective of cultural heritage- and the content of this space, including its didactic aspects. The Espai corbat has contributed throughout its ten years of operation to the dissemination of cultural heritage through bentwood furniture, particularly from Valencia. It has done so not only through the physical headquarters at the Foundation, but also through the promotion of various exhibitions in which the furniture collection has been represented.

Espai corbat, Exhibition, Fundació Caixa Vinaròs, Rocking Chair, Bentwood Furniture. 


\section{Introducción}

Dentro del mundo de los artefactos-asientos, las mecedoras de madera curvada, hoy ya casi nada utilizadas, constituyeron un hito importante en la evolución de la cultura material de las clases burguesas y medias del mundo occidental desde mediados del siglo xIx hasta mediados del siglo xx. En el caso español este impacto de las mecedoras todavía fue más acusado y perduró, con otros parámetros estéticos, hasta los años sesenta.

La historia del diseño industrial explica la caída en desuso de las mecedoras y su progresiva sustitución por otros tipos de asientos -incluidos los fabricados con acero tubular a partir de finales de los años veinte del siglo pasado-, con los que las mecedoras tienen una peculiar relación. En consecuencia, y aunque todavía es posible encontrar algunos productores de mecedoras de madera curvada, el interés expositivo de este campo de estudio y sus objetos se limita históricamente a un período de setenta años, hasta los años treinta del siglo xx.

La mecedora de madera curvada procede de las mecedoras de hierro de mediados del siglo XIX, en particular de un fabricante inglés llamado R. W. Winfield (1800-1869) que presentó una en la Exposición Universal de Londres de 1851 en la que Michael Thonet (1796-1871) participó. En 1860 surgió la primera mecedora hecha enteramente con madera curvada de la fábrica de Koritschan, en Moravia, de la firma Hermanos Thonet, empresa creada por Michael Thonet y sus hijos en 1853. La mecedora $n .^{\circ} 1$ de Thonet fue presentada al público en la Exposición Internacional de Londres de 1862, y cuando terminó la patente para el curvado de madera maciza, en 1869 , numerosos fabricantes se aplicaron en la producción de mecedoras de similar estilo llegando a haber hasta 50 modelos diferentes en los

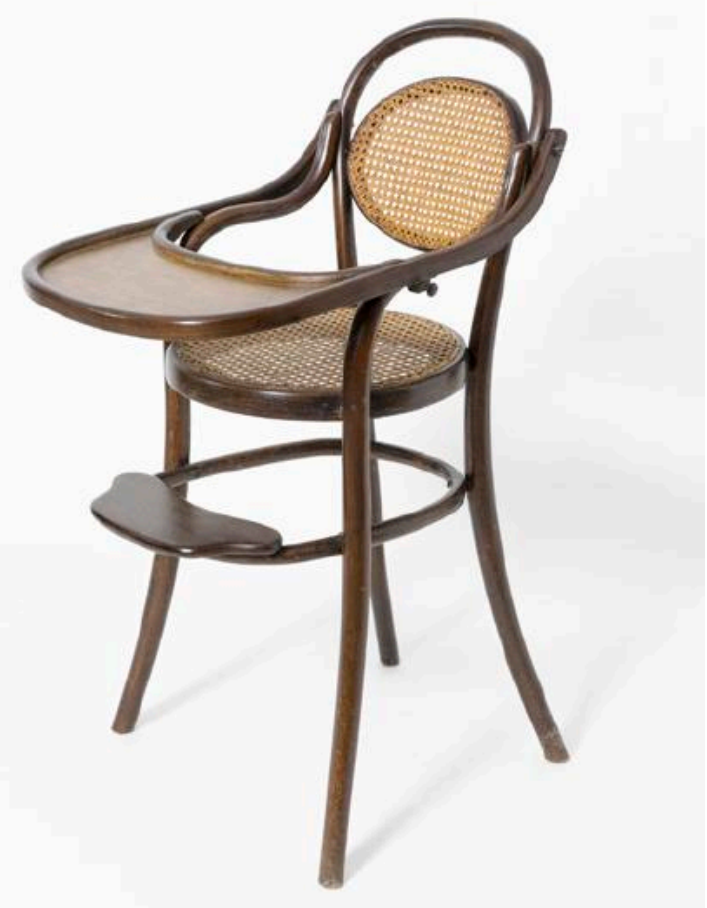

Trona de Hijos de D.G. Fischel (Bohemia). Espai corbat. Fundació Caixa Vinaròs. Fotografía: Luis Vives Chillida.

catálogos de los fabricantes más importantes, en torno al $1900^{1}$.

\section{El mueble curvado en Valencia}

Uno de los aspectos más destacados de la industrialización valenciana en el campo del mueble curvado es el carácter excelente y, en cierta medida, original, de la construcción de las mecedoras. Esto es así hasta el punto de convertir este mueble en lo que, hoy diríamos, es un producto típicamente mediterráneo, consumido en todo el arco, incluyendo particularmente Cataluña, Valencia, las Islas Baleares, Murcia y Andalucía. En este sentido, en cuanto a las mecedoras antiguas fabricadas

1 Sobre las mecedoras vienesas de madera curvada, véase el libro citado en la bibliografía de Chiara Renzi, Giovanni Renzi y Wolfgang Thillmann. El libro, partiendo de las mecedoras de Hermanos Thonet examina también las de otros fabricantes vieneses. 


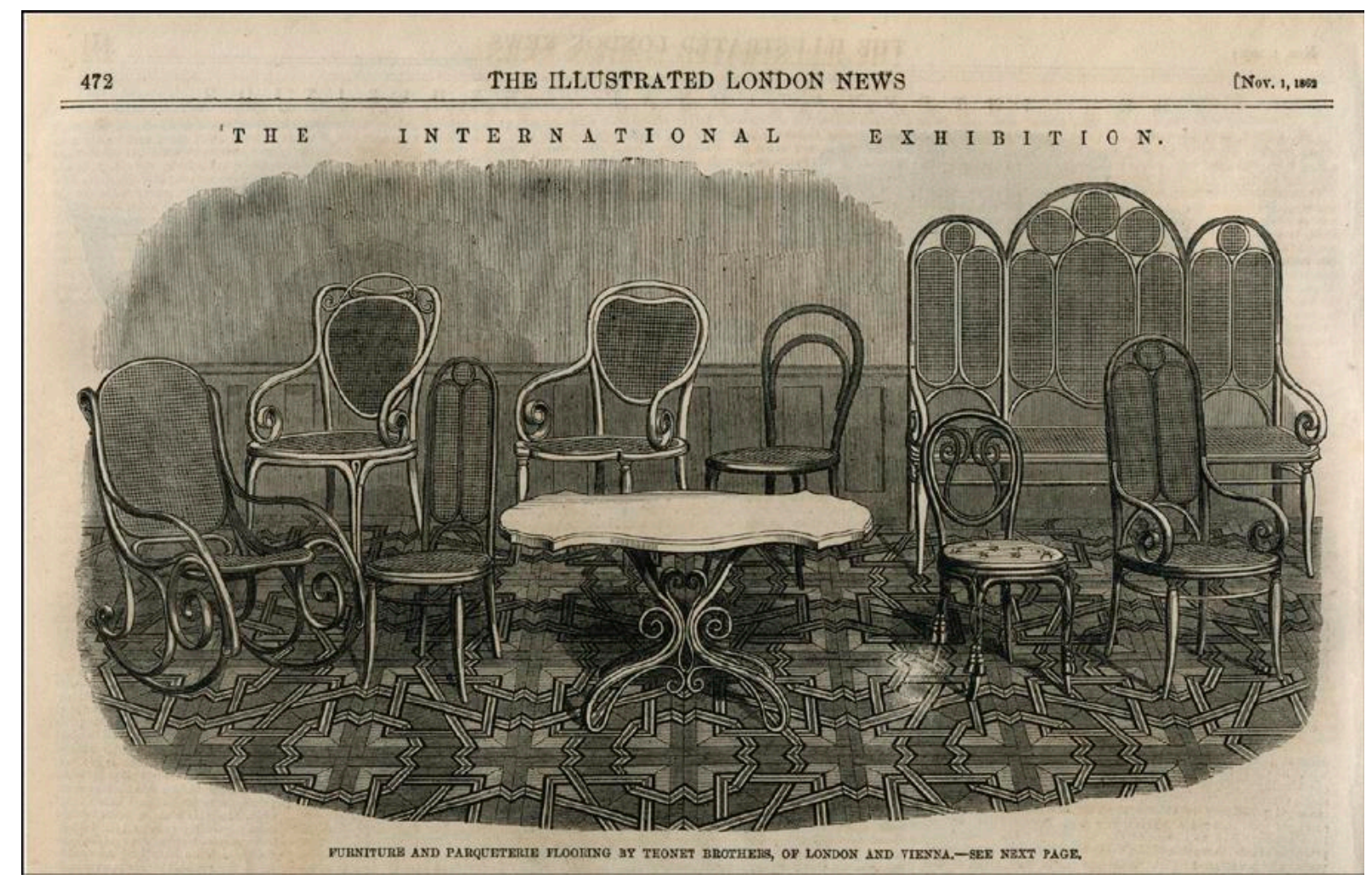

Muebles de Hermanos Thonet en la Exposición Internacional de Londres de 1862: The Illustrated London News, 1 nov. 1862.

en Valencia, se puede calificar a estos objetos como formando parte del patrimonio cultural valenciano de naturaleza industrial.

¿Cómo llegó a Valencia esta industria nacida en Viena? Martínez Ferrando decía, en 1933, que la industria del mueble en Valencia y sus fabricantes «...muestran un sello personal»; tiene una «sorprendente facilidad de asimilación» y fabrican un tipo de mueble curvado que «iguala, y en algunos modelos supera, a las manufacturas de Viena, que fue, como ya sabemos, su cuna» (1953: 105).

En consecuencia, no se trataba de una industria endógena, sino esencialmente asimilada de la ciudad austriaca, como ocurrió en otros países del entorno, concretamente en Italia. Es cierto que en Valencia ya había una larga tradición de ebanistería en la realización de muebles, y también de toneles para el vino, cajas para la fruta, abanicos, etc. Lo cierto es que influyó mucho la vitalidad del puerto y las relaciones comerciales, que a través de él, se establecieron a finales del siglo xIX y principios del xx con Austria-Hungría, a partir sobre todo de los puertos de Trieste y Fiume -actual Rijeka, Croacia-, principales centros comerciales y de transporte marítimo del Imperio centro-europeo. La compañía naviera húngara Adria, con sede en Fiume, hacía el transporte entre los diversos puertos y cargaba naranjas de vuelta para Austria-Hungría (anuncio de la compañía naviera del Almanaque Las Provincias, 1912: 276). Por mar llegaban los muebles y los catálogos comerciales con los diseños, pero también la madera ya preparada para trabajar, por la carestía de su transporte terrestre en España, y posiblemente también trabajadores de fábricas vienesas experimentados en el curvado. Al importarse la madera de Austria-Hungría, esta materia prima escaseó durante la Primera 


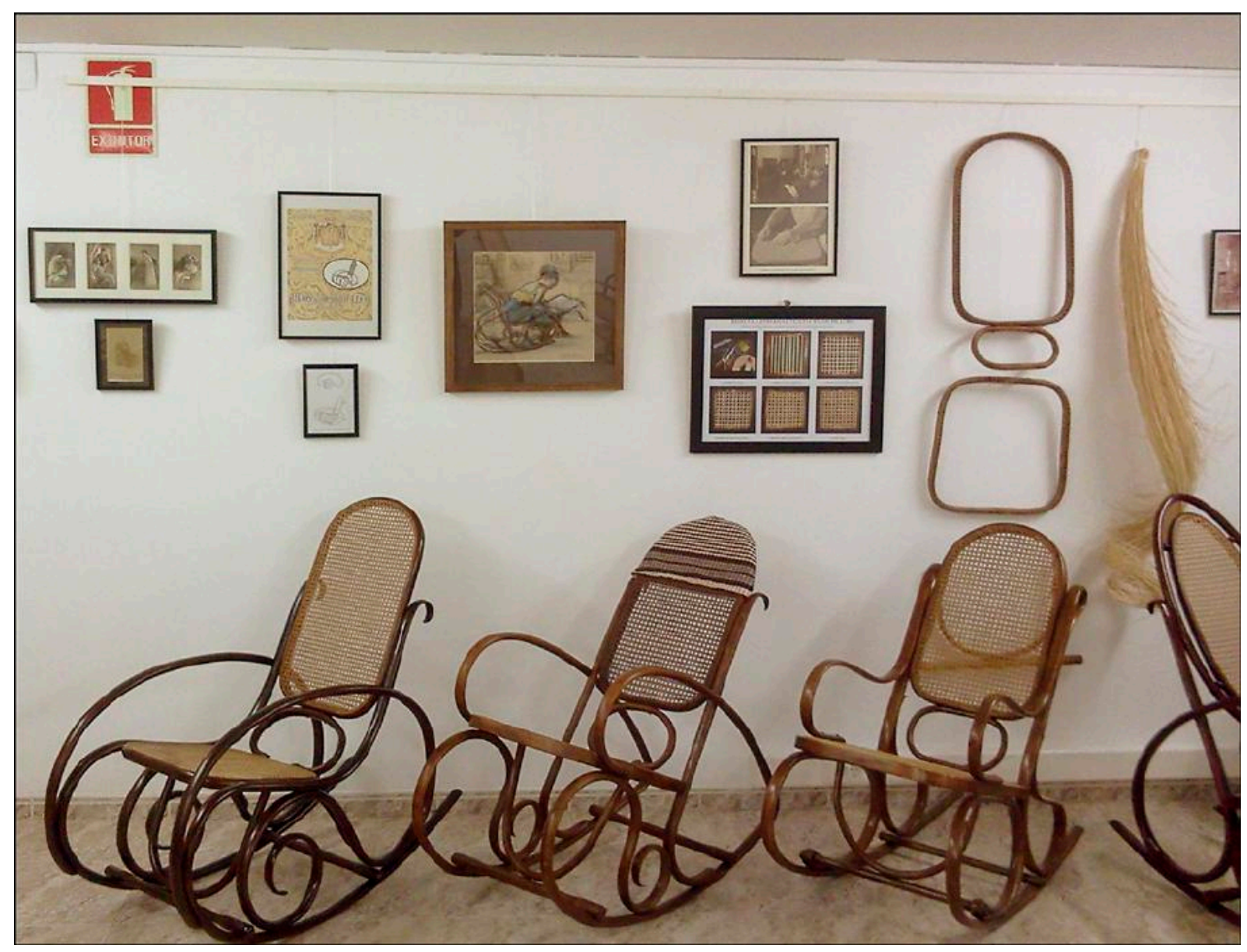

Interior del Espai corbat. Fundació Caixa Vinaròs. Fotografía: Julio Vives Chillida.

Guerra Mundial y llevó a una situación en que algunas fábricas de mueble curvado no pudieran trabajar todos los días de la semana. Un informe de 1914 sobre los efectos de la guerra en la industria decía:

En la provincia de Valencia, en la que la industria de trabajo y de la aplicación de madera curvada alcanza un gran desarrollo, contribuye, en la actualidad, al paro en las serrerías la dificultad que existe, por efecto de la guerra, en la importación de la materia necesaria para esta industria, que, en circunstancias normales, se recibe de Austria, por la vía de Trieste, de tal manera que esas fábricas que se dedican en especial al trabajo de esa clase de maderas, sólo funcionan, en el día, tres días a la semana (Instituto de Reformas Sociales, 1914: 31).
Según la tabla que aparece en el mencionado informe, 1000 kilos de madera de haya transportadas desde Arnedillo -Logroñocostaban, por todos los conceptos, 178 pesetas, y desde Trieste en las mismas condiciones, incluidos seguro y derechos aduaneros, 120 pesetas, siendo la diferencia de 58 pesetas (Instituto de Reformas Sociales, 1914: 32). Con ocasión de la Primera Guerra Mundial el mueble curvado de Valencia ocupó el espacio comercial que dejaba el mueble austro-húngaro (Soler, 1984: 59).

En algunos países europeos, como Alemania, Austria y Francia, hay espacios dedicados permanentemente a exponer mueble curvado, en particular vienés. Existen museos con mueble de Thonet en Frankenberg -Ale- 


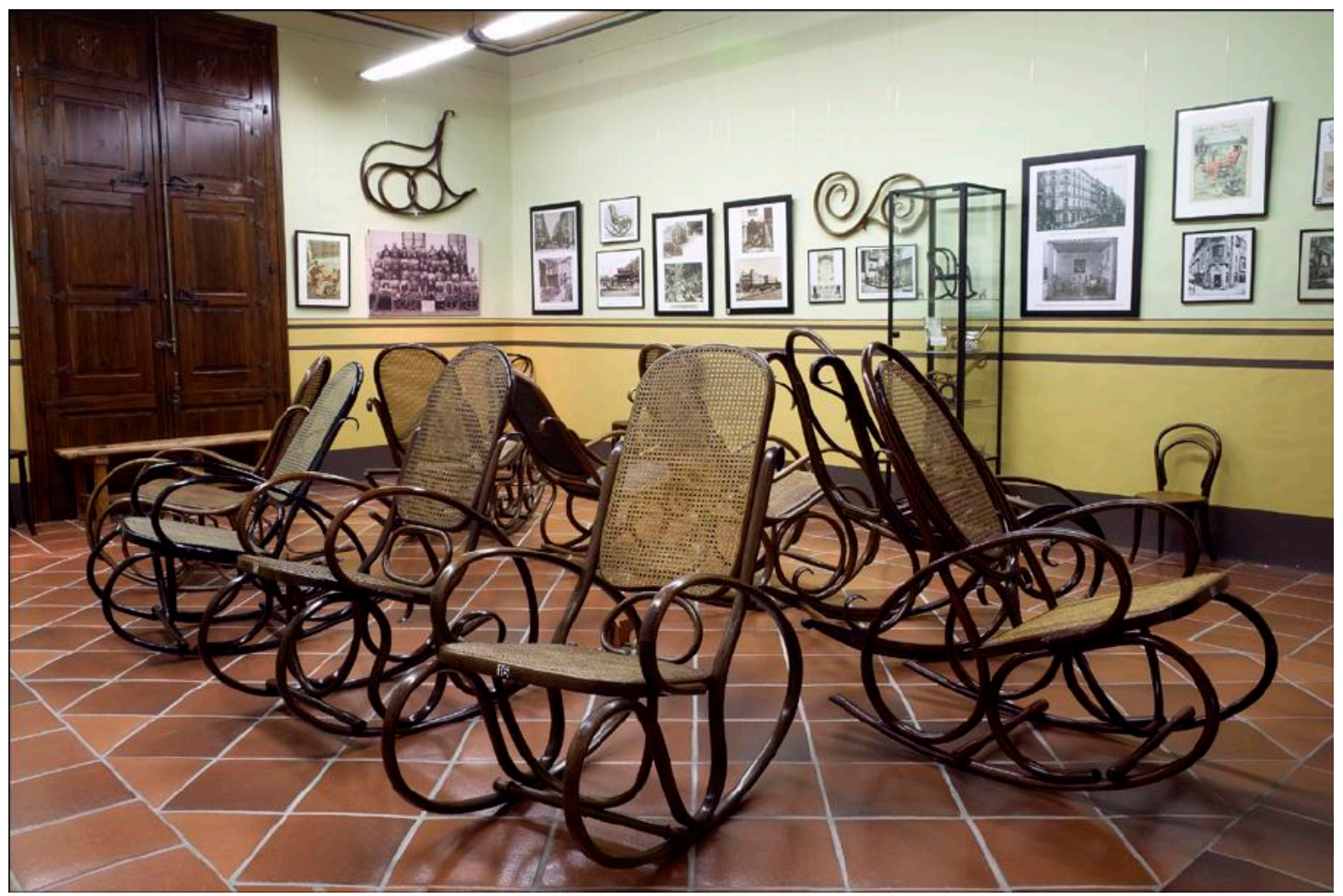

Mecedoras en la exposición de la Fundació Caixa Vinaròs, 2011. Fotografía: Luis Vives Chillida.

mania-, sede de la principal empresa Thonet actual; en Friedberg -Austria- y en el museo de la ciudad de Boppard am Rhein, localidad natal de Michael Thonet. En Austria destaca la colección del Museum für Angewandte Kunst (MAK) y en París hay una significativa colección de mueble curvado en el Musée d'Orsay. Estos dos últimos museos tienen página web donde puede observarse su colección. Pero no existía una exposición o espacio museístico de estas características en España. Esto es sorprendente si se tiene en cuenta la importancia del mueble de madera curvada en este país, en particular en Valencia, y de la relevancia de la importación de mueble vienés de las mismas características entre 1880 y 1914. Desde los inicios de la Primera Guerra Mundial, en la que Austria-Hungría, país de procedencia del mueble de importación, era potencia beligerante, el mueble curvado valenciano tuvo una fase de expansión considerable en España, al interrumpirse las importaciones de aquel mobiliario por el conflicto mundial. La importancia de las vías de comunicación marítimas se muestra en el hecho, como se ha dicho, de que no solo los muebles venían de los puertos de Trieste y Fiume, sino también la madera con la que se iban a construir los muebles valencianos. Progresivamente, cuando cambiaron las condiciones económicas y el transporte, se iba sustituyendo la madera de haya de Austria-Hungría por la de Navarra y La Rioja, donde algunos fabricantes valencianos acabaron localizándose.

Uno de los presupuestos teóricos de las propuestas de preservación actual del mueble curvado valenciano es que, dado el nivel alcanzado de los estudios sobre el tema, ya podemos distinguir, con certeza razonable, entre el mueble originario de Viena y el fabricado 
en Valencia. La copia de los modelos ideados por Michael Thonet y sus hijos -Hermanos Thonet- es un fenómeno muy conocido y se practicó en primer lugar en la propia Austria-Hungría por fabricantes como Jacob \& Josef Kohn -Moravia- e Hijos de D. G. Fischel -Bohemia-, entre muchos otros, hasta que, con el paso del tiempo, editaron sus propios modelos de mueble y compitieron con Thonet en condiciones de igualdad. En España hubo una importación significativa de mueble curvado vienés en torno a la década de 1890 hasta que surgieron los propios fabricantes locales ya cerca del 1900. Un ejemplo de esta importación se encuentra en la presencia de este tipo de mobiliario en las instalaciones de la Exposición Regional valenciana de 1883 (Real Sociedad de Amigos del País, 1883). La época de interés relevante para el estudio y exposición del mueble curvado valenciano es, por tanto, aproximadamente, entre 1900 y 1936, hasta la Guerra Civil. Los fabricantes valencianos de mueble curvado no solo copiaron los modelos vieneses, sino que también intentaron distinguirse en algunos aspectos, en particular en los diseños de las mecedoras y las sillas, incluyendo las trabas -refuerzo entre las patas- de las sillas, sillones y sofás.

\section{Orígenes del Espai corbat}

La Fundació Caixa Vinaròs es una institución cultural dependiente de la entidad bancaria Caixa Rural Vinaròs. Se constituyó en abril de 2000 y su objetivo primordial es organizar todo tipo de actos tendentes a la promoción cultural. El edificio principal de la Fundación en el centro de la ciudad, es la llamada «Casa Membrillera», una casa señorial rehabilitada en la calle de la Mare de Déu del Socors n. ${ }^{\circ} 64$.

Teniendo en cuenta los antecedentes teóricos señalados, la Fundació Caixa Vinaròs, como parte de su función de promoción cultural, inició a partir del 2010 una labor de estudio, difu-

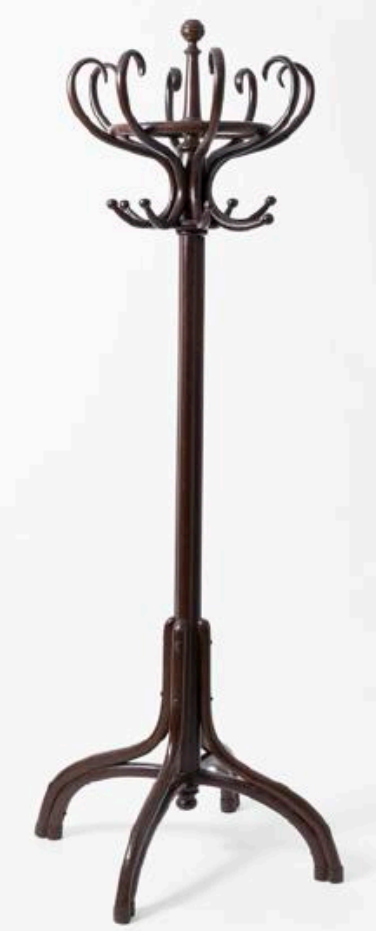

Perchero giratorio de Hermanos Thonet. Espai corbat. Fundació Caixa Vinaròs. Fotografía: Luis Vives Chillida.

sión y colección de mueble curvado, sobre todo, valenciano, entendiendo que era una laguna del campo del mobiliario en España, reconociendo, no obstante, los estudios seminales de diversos autores (Lecuona y Martínez, 1998).

El primer peldaño que condujo a la creación del Espai corbat se sitúa en el verano de 2011, cuando tuvo lugar la primera exposición con mueble de madera curvada en la sede de la Fundació Caixa Vinaròs. En esta muestra se podía contemplar mueble diverso, principalmente mecedoras, tanto valencianas como vienesas, y también sillas, distribuidas en varios espacios del edificio de la Fundación.

A continuación, y dado el éxito de esta exposición, la Fundación recibió una donación de mecedoras valencianas -veinte ejemplares inicialmente- y de Murcia. Estas piezas de la colección de la Fundación son todas diferentes y en su gran mayoría están identificados sus fabricantes. Los empresarios productores mejor representados son Ventura Feliu e Hijos, Ale- 


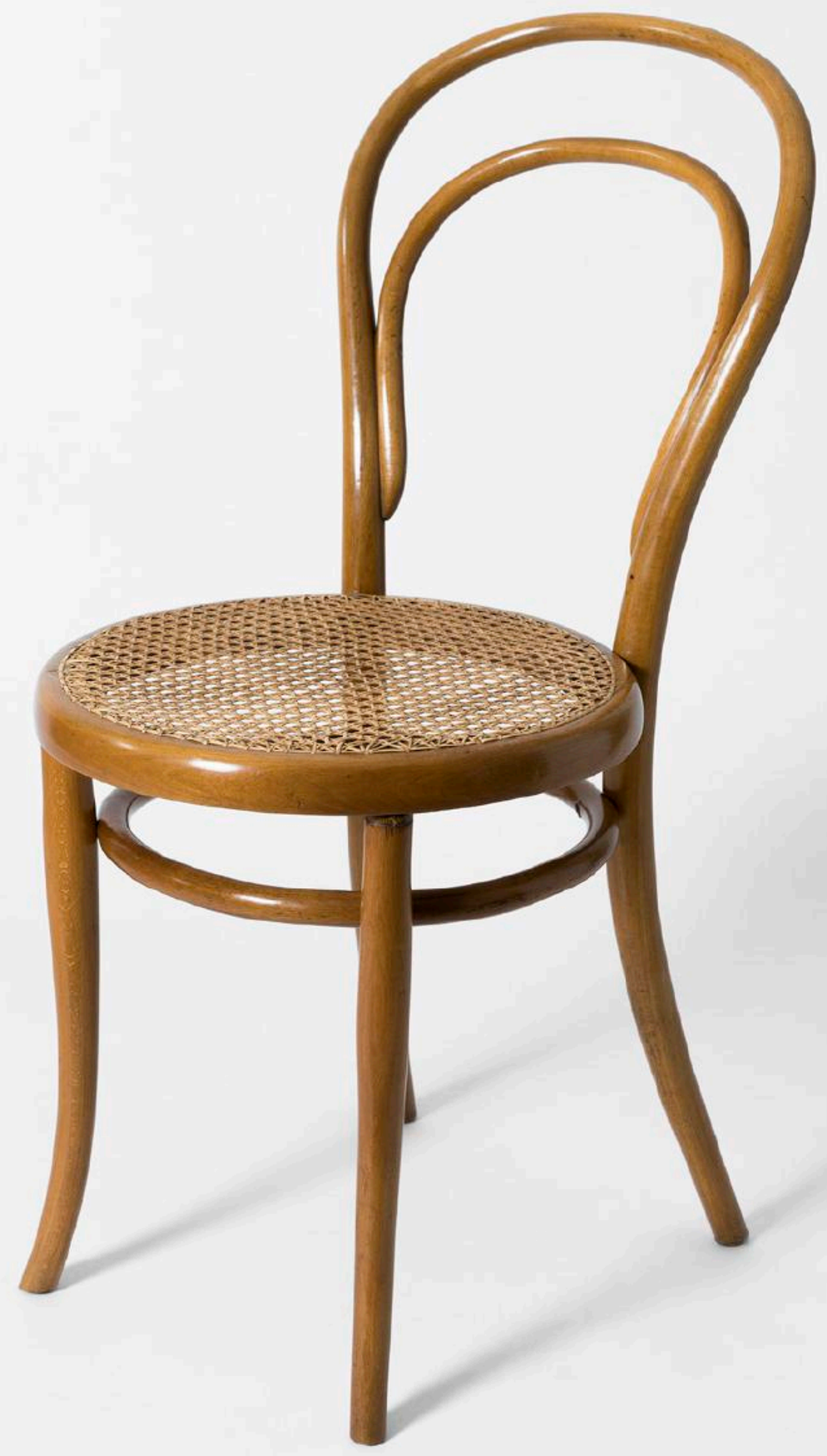

Silla n. ${ }^{\circ} 14$ de Hermanos Thonet. Espai corbat. Fundació Caixa Vinaròs. Fotografía: Luis Vives Chillida. 


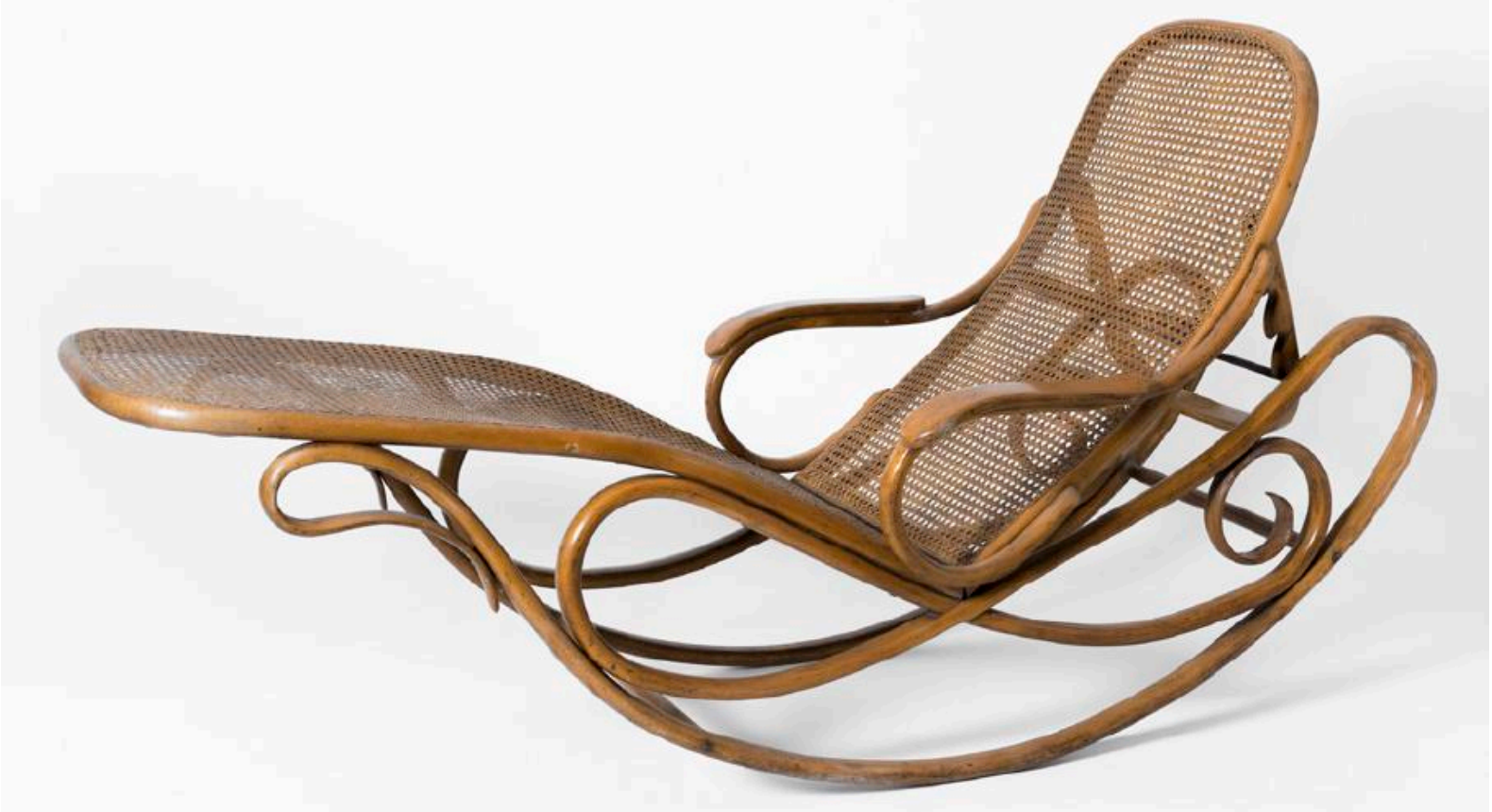

Chaise longue de Hermanos Thonet. Espai corbat. Fundació Caixa Vinaròs. Fotografía: Luis Vives Chillida.

jandro Delgado y Cía. (1836-1904), Salvador Albacar (1858-1928), Luis Suay (1846-1917) y Joaquín Lleó e Hijos. También hay ejemplares de Ramón Sanchís, Ramón Giménez y Julio Benedito. El estado general de las mecedoras, con señales de uso, es bueno, y en algunos casos se ha procedido a su mejora o restauración.

Por aquellas fechas la Fundación se convirtió en titular de los bajos de un edificio en la calle Almería n. ${ }^{\circ} 1$ de la ciudad, el local de las Amas de Casa de Vinaròs. Entre otros espacios de interés, como, inicialmente, el Centro de Documentación de la Guerra Civil de Vinaròs, se decidió situar en este edificio un nuevo Espacio para acoger las mecedoras de la Fundación: el Espai corbat. Este nuevo espacio se añadía, complementando, a otros de los que la Fundación ya disponía como el Espai mar, el Espai camp y el Espai industria, representativos de la actividad pesquera, agrícola e industrial de la ciudad, respectivamente.

\section{Características e interés público}

El Espai corbat es el espacio físico y cultural donde se expone mueble curvado, principalmente valenciano. Se trata de una exposición permanente, abierta al público habitualmente un día a la semana según la disponibilidad de personal. No es en ningún caso un museo en sentido pleno, si bien en la difusión del espacio se emplea en ocasiones la palabra «museo»-museo de la mecedora- por su carácter pedagógico respecto a la función que cumple en el sentido de remarcar al público potencial que no es un establecimiento comercial con el que en ocasiones se le ha confundido. La entrada es gratuita.

El espacio físico del que se dispone para la exposición de las mecedoras y la iconografía es bastante limitado. En unos $50 \mathrm{~m}^{2}$ se colocan las mecedoras con un orden por características y estilos, y en un sector de la sala se incluyen las estructuras de asiento y respaldo de una mece- 
dora con un haz de rejilla y un panel -diseñado por los restauradores Mariona Velasco y Xavier Duch-sobre el modo de su elaboración, junto a un molde metálico para hacer mecedoras, elementos que más adelante comentaremos. A la altura de cada mecedora, en las paredes, se coloca la correspondiente iconografía ilustrativa de modo que puede hacerse un seguimiento pieza por pieza. En una sala contigua se encuentra el salón vienés. En ambas salas está disponible la documentación necesaria para la difusión, incluidos catálogos. Un libro de firmas recoge las impresiones de los visitantes.

Actualmente el conjunto del Espai corbat no tiene oficialmente la consideración de colección museográfica, aunque indudablemente su contenido forma parte del patrimonio cultural valenciano según la legislación vigente. En efecto, por lo que se refiere a las mecedoras antiguas fabricadas en Valencia, se las puede calificar como parte del patrimonio cultural valenciano de naturaleza industrial. Según la Ley de Patrimonio Cultural Valenciano de la Generalitat Valenciana de 11 de junio de 1998:

\begin{abstract}
El patrimonio cultural valenciano está constituido por los bienes muebles e inmuebles de valor histórico, artístico, arquitectónico, arqueológico, paleontológico, etnológico, documental, bibliográfico, científico, técnico, o de cualquier otra naturaleza cultural, existentes en el territorio de la Comunidad Valenciana o que, hallándose fuera de él, sean especialmente representativos de la historia y la cultura valenciana (Artículo 1, párrafo 2 de la Ley).
\end{abstract}

Sin duda, si se utilizan los parámetros de los estudios sobre etnología, historia y diseño industrial, las mecedoras antiguas constituyen objetos muebles de naturaleza industrial, que por su incorporación a nuestra cultura material forman parte de su patrimonio; son representativos de nuestra cultura y en consecuencia es un acervo que merece ser divulgado. Por otro lado, si consideradas individualmente las mecedoras son bienes muebles no inventariados, según el párrafo c) del artículo 2 de la mencionada Ley, esto no excluiría que se pudiera declarar como bien mueble de interés cultural el conjunto de una colección -artículo 26.1. B de la Ley-. En cualquier caso, según el artículo 87, titulado «interés público»:
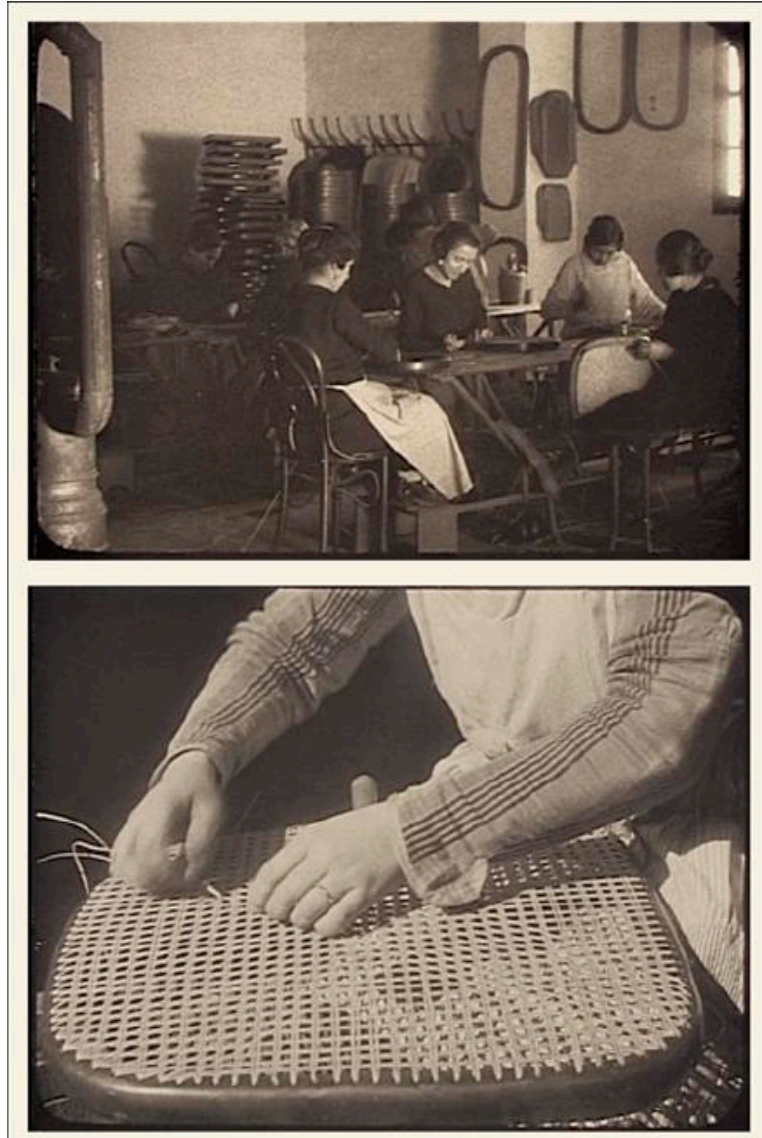

Mujeres haciendo rejilla en la fábrica de Ventura Feliu: selección de fotogramas de la película Hijo de Ventura Feliu de 1929. Filmoteca de Catalunya.

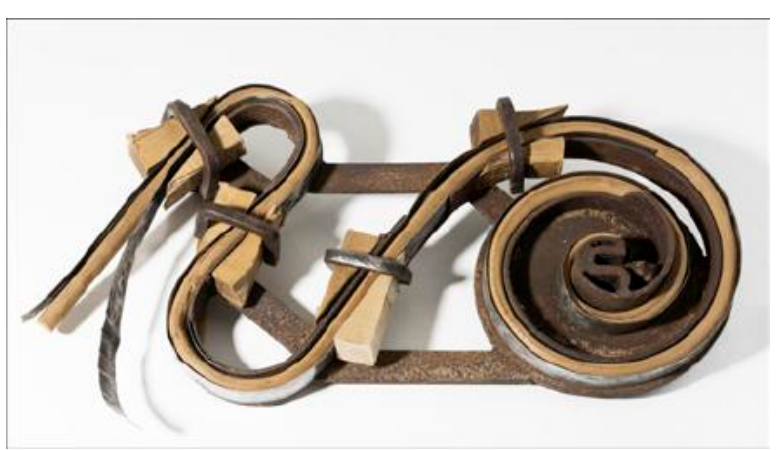

Molde metálico para fabricar la espiral de una mecedora. Espai corbat. Fundació Caixa Vinaròs. Fotografía: Luis Vives Chillida. 


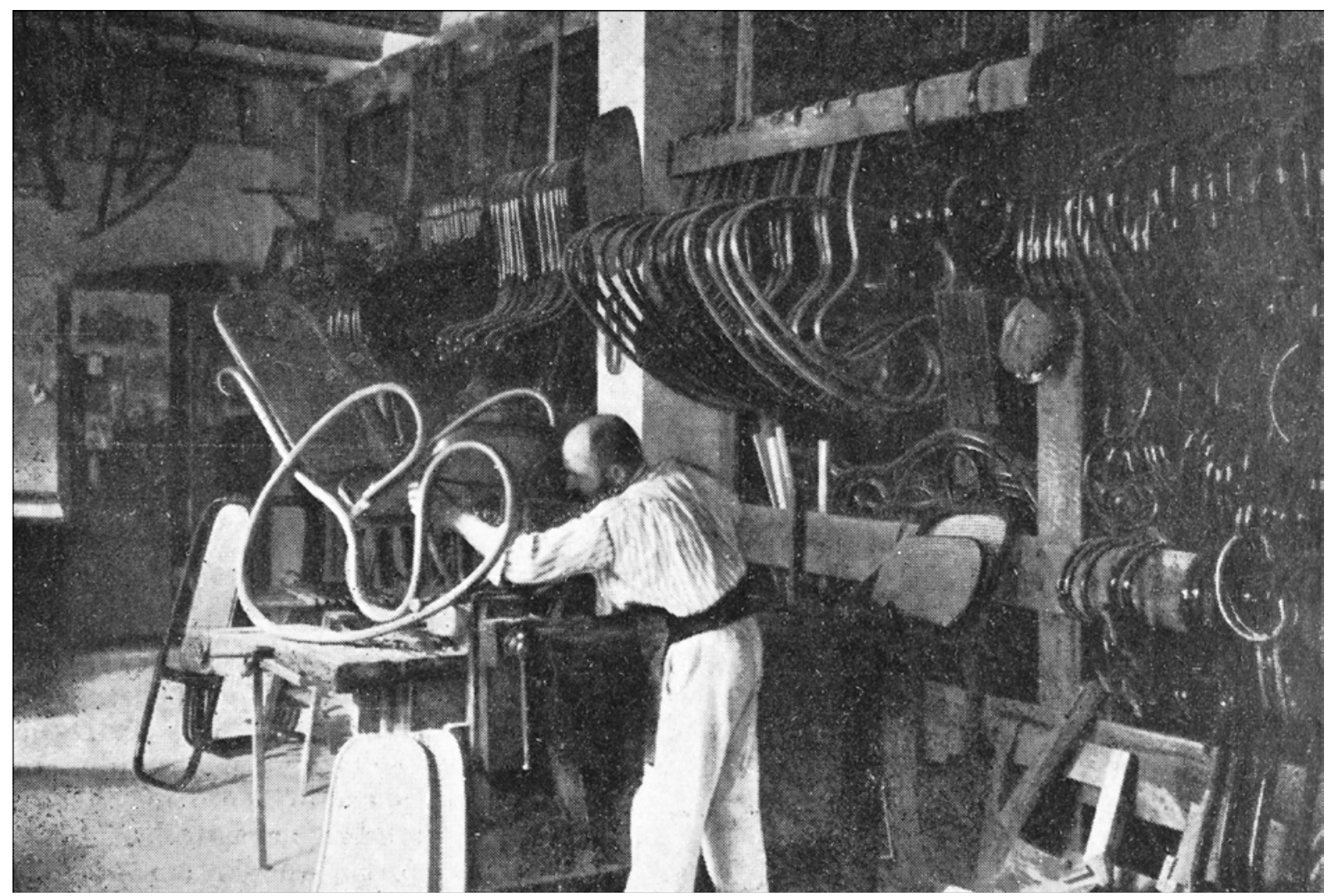

Trabajador de la fábrica de Luis Suay montando una mecedora. Revista Por esos mundos, 1911.

Se reconoce el interés público de todas las actividades de conservación y promoción del patrimonio cultural valenciano y su carácter de fuente de riqueza económica para la colectividad. Las administraciones públicas de la Comunidad Valenciana deberán cooperar a dichas actividades, cuando sean desarrolladas por los particulares, mediante la concesión de las ayudas materiales y el reconocimiento público adecuado, proporcionados a la utilidad social que reportan y a las cargas que suponen para los propietarios.

En este sentido, el Espai corbat supone un reconocimiento del interés público de la colección por parte de una institución cultural como la Fundació Caixa Vinaròs.

\section{Contenido y elementos didácticos}

Actualmente, tras sucesivas ampliaciones de la donación inicial, en el Espai corbat hay trein- ta y cinco mecedoras, incluyendo mecedoras infantiles. Las mecedoras para la infancia eran muy populares en Valencia y se hacían con las mismas formas que las mecedoras para adultos a escala, cosa que no se hacía por los fabricantes de Viena. Su ámbito temporal aproximado de fabricación es de 1900 a 1936 y, en consecuencia, la mayoría tienen más de cien años. Algunas responden a patentes que se registraron a principios del siglo xx. Desde el punto de vista de los estilos, encontramos mecedoras con espirales en los laterales, con aros, modernistas (como las que tienen los laterales formados por una sola barra continua o por un lazo), streamline $e^{2}$ también modernas cuando

2 Este término deriva del mundo del diseño y se puede aplicar a algunas mecedoras. El streamline en español se llama «estilo aerodinámico» $\mathrm{o}$ «aerodinamismo», y surgió a mediados de los años treinta en los Estados Unidos. Aquí se emplea para designar mecedoras que tienen estas características porque el estilo destacaba por sus formas curvas y líneas largas. 


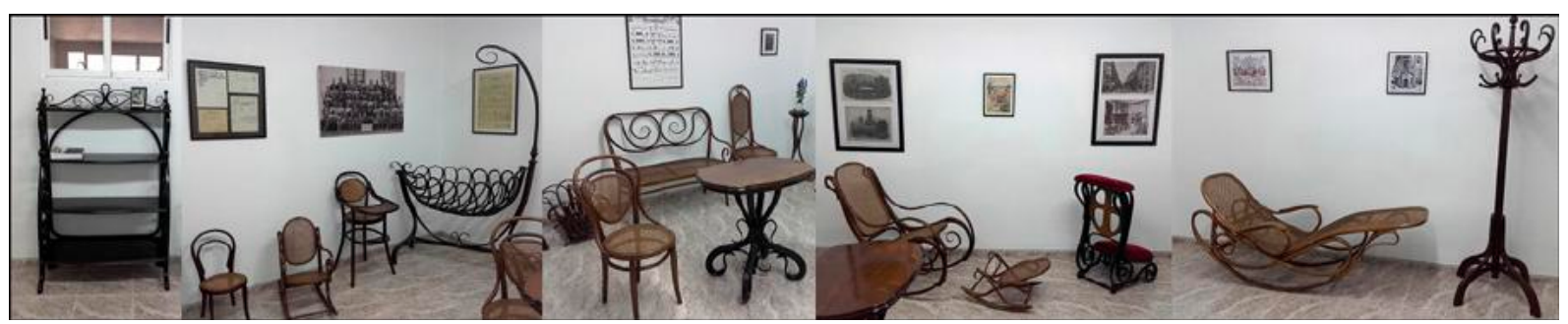

Reconstrucción panorámica del salón vienés. Espai corbat. Fundació Caixa Vinaròs (2017). Fotografías: Julio Vives Chillida.

son predominantemente funcionales, sin decoración. En conjunto son una muestra representativa tanto del elevado nivel de la industria valenciana del mueble curvado en el período considerado como de los diferentes modelos de mecedora que se fabricaban en el primer tercio del siglo $\mathrm{xx}$. A los efectos de poner en valor el conjunto de la colección reunida, en 2013 se publicó un documento con la catalogación de las piezas reunidas hasta el momento y para facilitar su comprensión en el contexto histórico y cultural de la industria valenciana y su origen vienés (Catàleg de la col-lecció de balancins, 2013). El sumario del catálogo, escrito en catalán, es el siguiente: 1 . Las mecedoras de madera curvada; 2. Patrimonio cultural; 3. Fabricación; 4. Clasificación; 5. Catalogación; 6 . El Espai corbat y 7. Bibliografía.

Desde un planteamiento didáctico, la exposición muestra no solo las mecedoras, sino también el procedimiento de elaboración de la rejilla, con un panel explicativo de cómo se ha de tejer -la mecedora es como un telar en su estructura- e imágenes de trabajadoras haciendo rejillas en la fábrica de Ventura Feliu (Película viviente sobre la fábrica de muebles curvados Hijo de Ventura Feliu, Valencia, 1929). Se trata de una película muda que posiblemente Enrique Feliu Raga, propietario único de la fábrica -su hermano Joaquín murió en un accidente de tráfico en 1925- encargó para la Exposición Internacional de Barcelona de 1929 en la que participó. La película, que está depositada en el archivo de la Filmoteca de Catalunya, muestra, con notas familiares y personales, el modo de producción de mueble curvado en Valencia en el primer tercio del siglo $\mathrm{xx}$ y tiene interés histórico desde la perspectiva de la arqueología industrial y la historia del mueble curvado.

La manera tradicional de elaborar la rejilla es formando un hexágono con seis tiras: dos horizontales, dos verticales y dos diagonales, a falta del remate. La resistencia y la belleza de la rejilla está reconocida pero también la dificultad de su sustitución manual en las mecedoras que se han de restaurar. Hacer rejilla es casi, hoy en día, un oficio en peligro de extinción que merece un reconocimiento, no solo por la dimensión artesana de su elaboración, sino también porque hay que tener en cuenta que era una fuente importante de la plusvalía de la industria del mueble curvado durante muchos años. Las mujeres hacían la rejilla en espacios habilitados para ello en la misma fábrica o en sus casas, trabajando a destajo ya que durante muchos años se cobraba por pieza hecha. Poco a poco la madera contrachapada fue sustituyendo a la rejilla en algunos muebles, como las sillas, pero perduraría muchos años en las mecedoras en Valencia como así se muestra en la colección de la Fundació Caixa Vinaròs, en la que todas las piezas están acabadas en su asiento y respaldo con la tradicional rejilla.

Otro elemento didáctico de interés en la exposición del Espai corbat es un molde metálico que se utilizaba para curvar las espirales de las mecedoras. La fabricación de las mecedoras de madera curvada sigue los procedimientos usuales en la producción del mueble curvado. Se han de serrar las barras de madera 


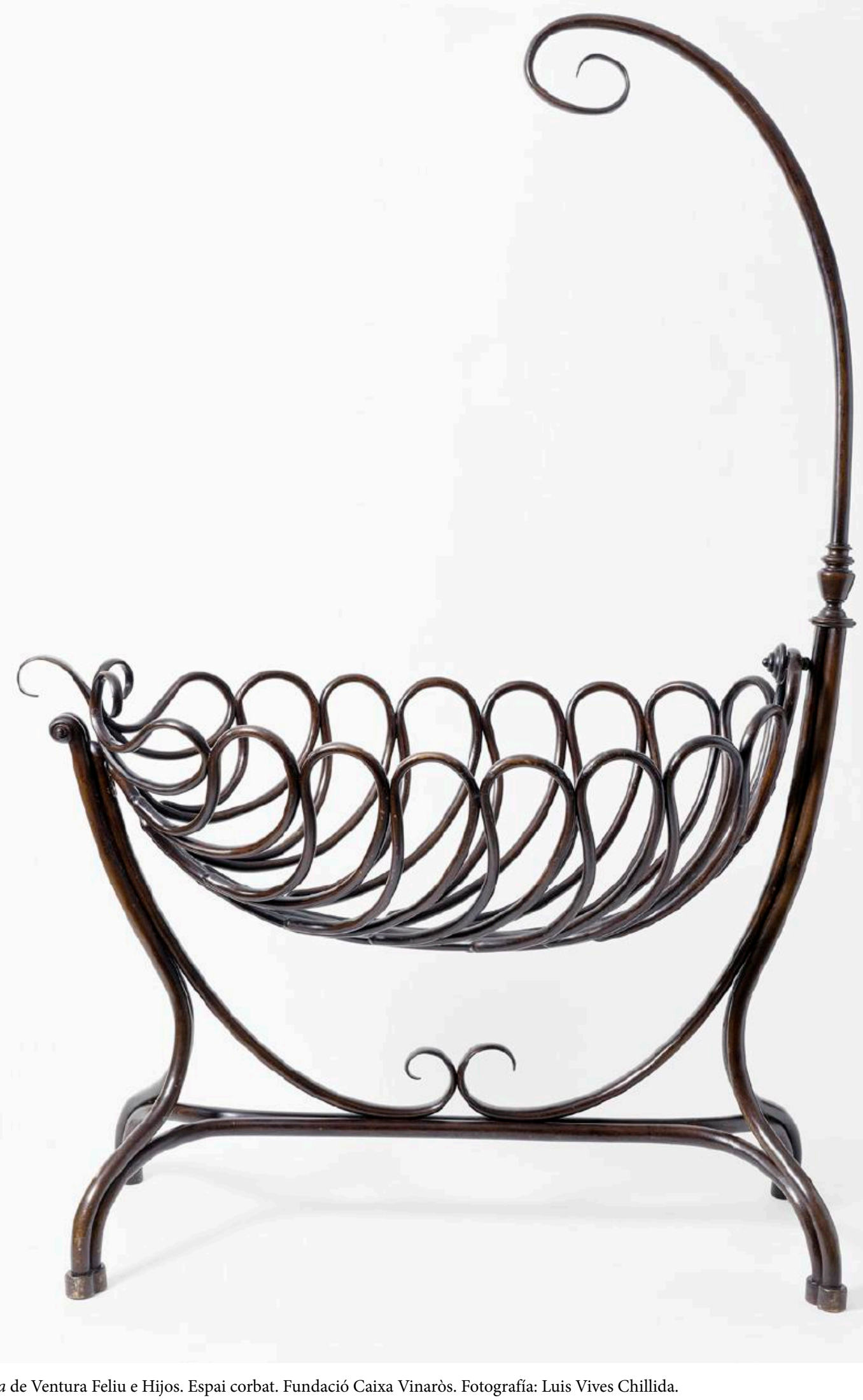




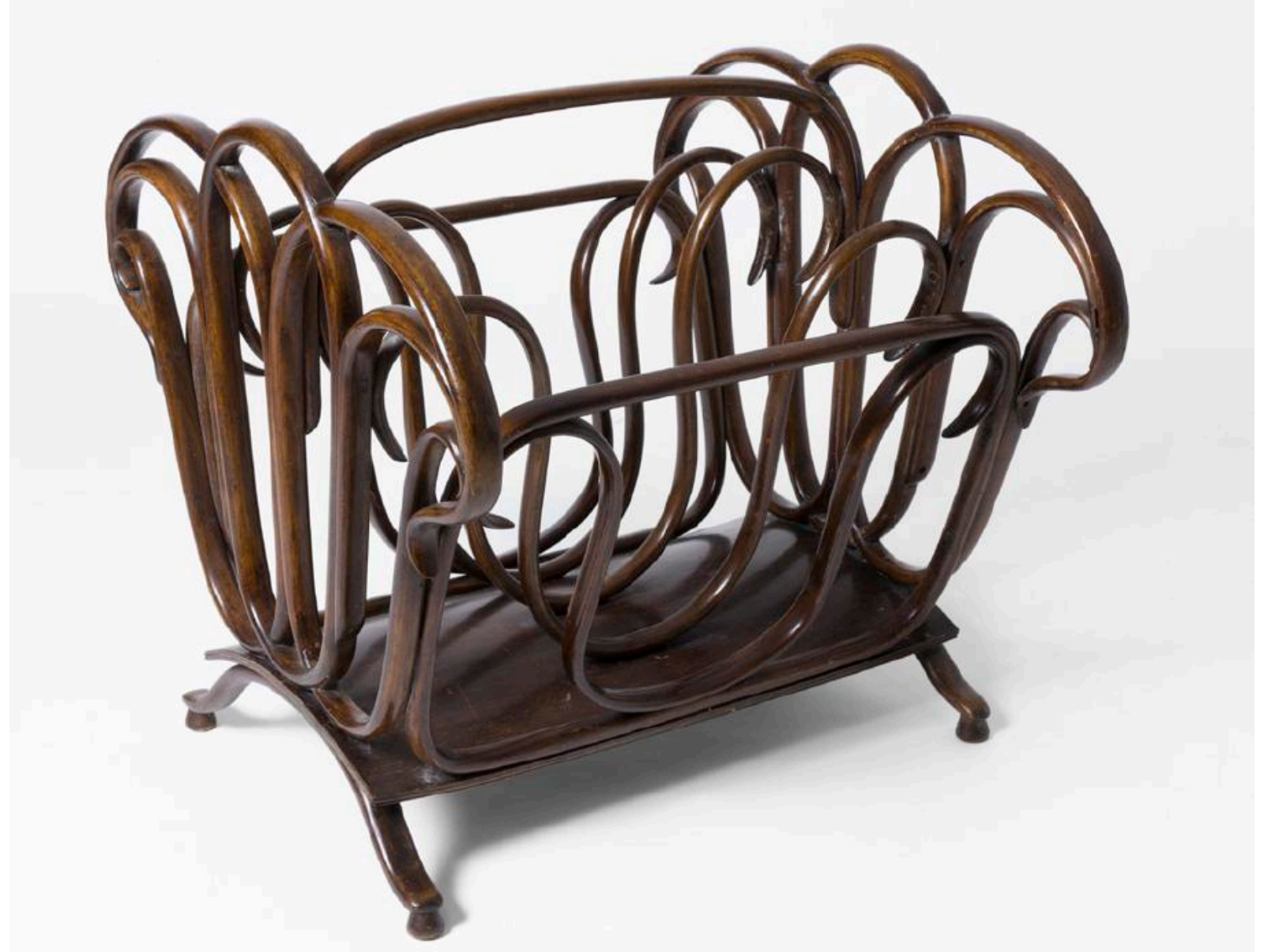

Musiquero de Jacob \& Josef Kohn. Espai corbat. Fundació Caixa Vinaròs. Fotografía: Luis Vives Chillida.

en la longitud necesaria. Después se calientan tales barras durante algo más de una hora -tiempo que dependía de la tecnología disponible- en tanques de vapor. Cuando salen de los tanques las barras se pueden doblar sin que se rompan, en caliente, pero se han de introducir en moldes metálicos para evitar la rotura de las fibras cuando la madera se enfría porque, se dice en este sentido, la madera tiene rabia. Cuando la madera se enfría en los moldes se sacan las barras que conservan así la forma. Entonces, una vez elaborados los asientos y respaldos pertinentes con rejilla, se unen las piezas de madera con tornillos -sin necesidad de encolar- y previamente pulidas, se barnizan en el color deseado y se embalan en papel para su expedición. Así se hacía en el primer tercio del siglo xx. La exposición en el Espai corbat viene acompañada también de material iconográfico diverso: fotografías, postales, retratos, algún cuadro y copia de un cuadro, anuncios, imágenes de catálogos, pósteres, imágenes de la película de la fábrica de Ventura Feliu de 1929 ya citada, entre otros documentos. Se trata de mostrar la producción, el comercio y el uso de las mecedoras en su contexto histórico, social y cultural de manera que se aprecie en todo su alcance la dimensión del objeto que es la base material de la exposición. En efecto, un aspecto esencial en la exposición para la puesta 


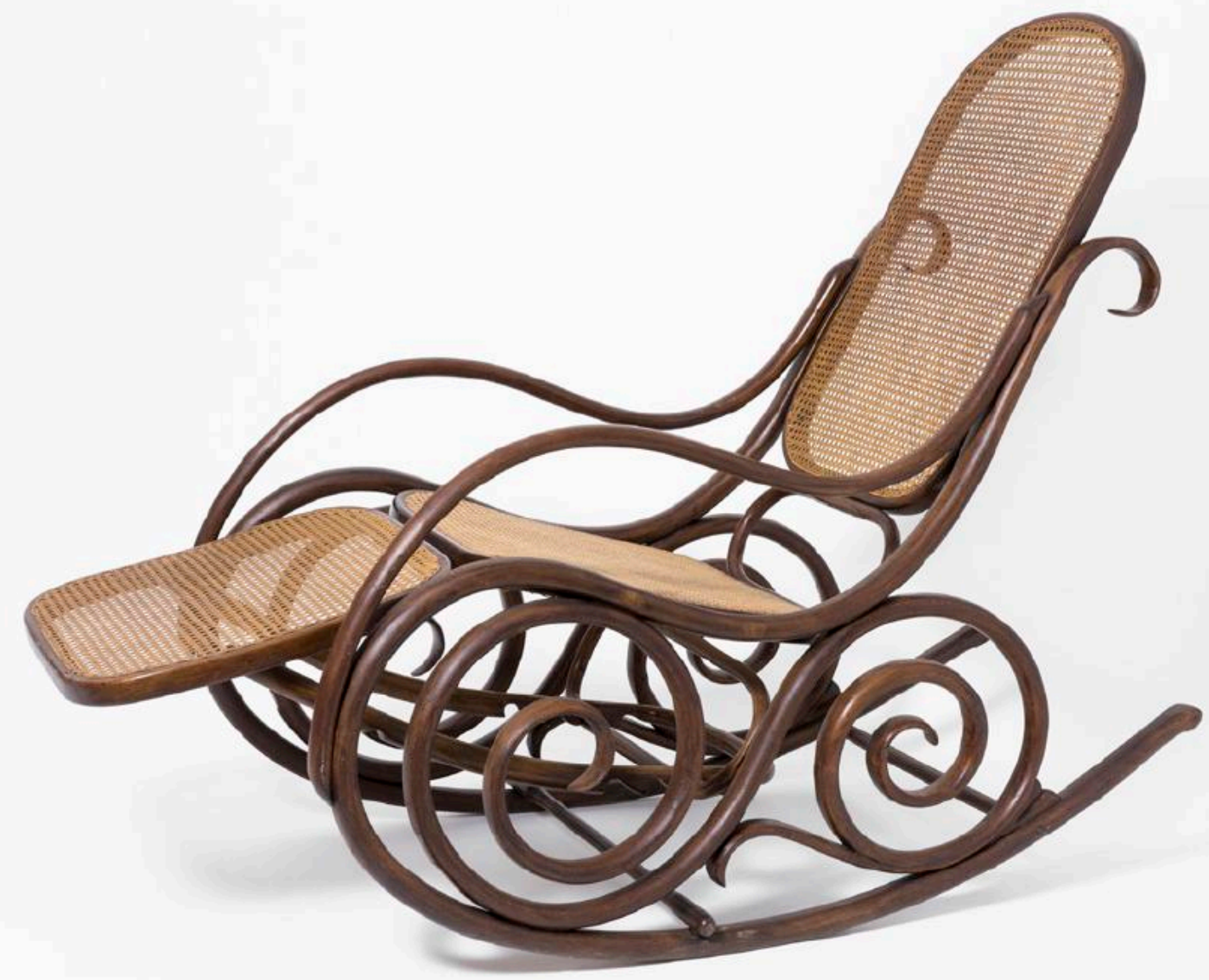

Mecedora n. 9 de Jacob \& Josef Kohn con reposapiés ajustable. Exposición en el Museo de la Ciudad de Benicarló (2019). Actualmente en el Museo Nacional de Artes Decorativas de Madrid. Fotografía: Luis Vives Chillida.

en valor de las mecedoras es la existencia de un conjunto iconográfico muy extenso y variado sobre su producción, su uso y consumo, lo cual permite exponer con un gran atractivo la integración del objeto en los usos y costumbres de la sociedad en sus diversos planos. La documentación expuesta afecta en ocasiones al propio diseño, cuando se trata de patentes, a la producción, incluida la elaboración de la rejilla y al montaje de las mecedoras (Valentí, 1911), al uso social, dado que la mecedora era un objeto predilecto a la hora de hacer retratos o postales de variadas características, tal era la fuerza icónica de este mueble. La exposición, junto con las mecedoras, de todo este material de imágenes históricas, subraya de una manera decisiva la presentación de los objetos que, por sí sola, podría considerarse limitada en el sentido en el que se consideraba limitado, por ejemplo, lo que se exponía sin orden ni estudio en los gabinetes de curiosidades del siglo XIX. Este es un punto en el que la exposición se abre a la participación del público, a la sociedad, recogiendo testimonios particulares que se quieran aportar en término de fotografías y otros documentos. Porque, a principios del siglo XXI, ¿quién no recuerda a un abuelo o abuela descansando, leyendo o cosiendo en una me- 
cedora de madera curvada en aquellos años en que no había sofás, ni televisión, ni aspirinas?

\section{Exposición sobre mecedoras vienesas mo- dernistas}

Como una actividad de divulgación del mueble curvado por el Espai corbat, del 31 de marzo al 14 de mayo de 2016, se celebró una exposición sobre mecedoras modernistas de Viena, procedentes de colección particular, en la sede principal de la Fundación. La mecedora de madera curvada es un mueble peculiar porque sus formas evocan la función de movimiento para la que ha sido diseñada. Por eso parece que está en movimiento incluso cuando el balancín está parado. Como hemos dicho, Hermanos Thonet, fabricantes principales de muebles de madera curvada de Viena, hicieron su primera mecedora en 1860. En 1862 la exhibieron en la Exposición Internacional de Londres y a partir de entonces Thonet comenzó a diversificar las formas de las mecedoras, que se hicieron muy populares. Otros fabricantes de Austria-Hungría como los citados Kohn y Fischel reprodujeron en sus catálogos las mecedoras de Thonet e innovaron ofreciendo sus propios modelos. En la época del modernismo se hicieron mecedoras que seguían este estilo por su estructura y/o su decoración. En esta exposición, la Fundación presentó en su día una selección representativa de mecedoras modernistas realizadas por dichos fabricantes vieneses entre 1880 y 1915 aproximadamente. Los fabricantes valencianos de muebles de madera curvada se inspiraron en algunas de ellas para diseñar sus propios modelos.

\section{El «salón vienés» del Espai corbat}

Una ampliación del Espai corbat se produjo en el verano de 2017 con la inauguración de una sala nueva denominada «salón vienés» a partir de una nueva donación particular. Se trata de una pequeña sala que reproduce, con muebles de madera curvada, un salón vienés del último tercio del siglo XIX reconstruido a partir de mobiliario seleccionado de fabricantes vieneses y valencianos que seguían el estilo de la ciudad austriaca, como Ventura Feliu y Salvador Albacar. Esta ampliación tipológica se añade a la sala original con mecedoras valencianas, de la que constituye un complemento que ilustra las posibilidades de fabricación de mobiliario curvado más allá de las mecedoras. La mayoría de los muebles expuestos en el salón tienen representación en museos de Europa y América ya sea por su relevancia histórica como arte decorativo, por la originalidad de su diseño con el lenguaje de la madera curvada, por su carácter funcional o simplemente por su belleza. Desde una perspectiva estética actual pueden calificarse estas piezas, que respondían a los estilos y gustos del pasado, de esculturas de madera curvada industriales y así se reflejó en el título de un prospecto editado para la ocasión (Escultures de fusta industrials: un saló vienès del segle XIX, 2017).

El salón está compuesto de 1. Cuna; 2. Jardinera; 3. Sofá; 4. Musiquero; 5. Trona; 6. Mecedora infantil; 7. Silla infantil; 8 . Silla de respaldo alto; 9. Mesa; 10 . Silla de comedor; 11. Reposa-pies basculante; 12. Mecedora; 13. Estantería; 14. Perchero; 15. Reclinatorio y 16. Chaise-longue basculante.

\section{Exposición sobre muebles curvados de Vie- na y de Valencia}

La última de las actividades de divulgación hasta el momento del Espai corbat y probablemente la más extensa y trabajada es la exposición de verano de 2019 (11 de julio al 22 de septiembre) en el Museo de la Ciudad de Benicarló (MUCBE). La exposición abarcaba mobiliario de la Fundació Caixa Vinaròs y al- 
gunos ejemplares procedentes de colecciones privadas. El objetivo de la exposición fue mostrar un conjunto de mobiliario hecho con la técnica del curvado de la madera, desarrollada por Michael Thonet y sus hijos durante el siglo xix. Los muebles vieneses expuestos eran de este fabricante y también de otros llamados «competidores» en Austria-Hungría como los reiterados Kohn y Fischel. En cuanto a los fabricantes valencianos, había representación de los más importantes: Hijos de Ventura Feliu, Hijos de Joaquín Lleó, Salvador Albacar y Luis Suay. Además, se presentaron dos espacios diferenciados que formaban un salón y un dormitorio, pues la madera curvada podía abarcar cualquier tipo de mobiliario para el hogar y no solo para establecimientos públicos como cafés y hoteles, como en ocasiones se da equivocadamente a entender. Estos espacios eran de algún modo una ampliación del salón vienés del Espai corbat. Esta exposición fue una muestra representativa del mueble curvado originario de Viena y de su recepción en Valencia, aspectos estos inéditos hasta el momento en exposiciones o museos. El catálogo de la exposición, accesible en internet, reproduce fotografías de todas las piezas que se mostraron en las amplias salas del MUCBE y también se encuentra en línea un video de la inauguración de la Exposición-Moble corbat de Viena i de València-.

\section{Balance y perspectivas}

El Espai corbat de la Fundació Caixa Vinaròs ha contribuido a lo largo de sus diez años de funcionamiento a la difusión del patrimonio cultural constituido por mueble curvado, especialmente mecedoras valencianas. Lo ha hecho no solo mediante la apertura de una sede física específicamente dedicada al objeto en la Fundación, sino también a través de la pro- moción de diversas exposiciones en las que el grueso de la colección de mobiliario ha tenido representación. Consideramos que es necesario un proyecto de este tipo para valorar una parte importante de la historia cultural e industrial de Valencia, en un sector que, si bien tiene su origen en influencias exteriores, tuvo una sólida implantación en dicho territorio y mostró características propias en algunos aspectos.

Las perspectivas de futuro son positivas tanto de cara a la consolidación del Espai corbat en el seno de la Fundación, como un proyecto de musealización incipiente, como de cara a la participación en acontecimientos culturales de su ámbito de trabajo en el futuro. El foco de las exposiciones previstas está puesto en el mueble curvado valenciano producido entre 1900 y 1936 aumentando la variedad tipológica de la colección. Sea como fuere, el Espai corbat es ya una experiencia de interés museístico y aspira a ser algún día una colección museográfica permanente reconocida en la Comunidad Valenciana.

\section{REFERENCIAS y Bibliografía}

Almanaque Las Provincias, 1912.

Catàleg de la collecció de balancins (2013) Vinaròs: Fundació Caixa Vinaròs.

Escultures de fusta industrials: un saló vienès del segle XIX. Prospecte d'exposició (2017) Vinaròs: Fundació Caixa Vinaròs.

Espai corbat. Disponible en https://www.fundaciocaixavinaros.com/espais/espai-corbat/ [Fecha de consulta $04 / 01 / 2021$ ]

Instituto de Reformas Sociales (1914) Resumen de las informaciones de los inspectores del trabajo acerca de las consecuencias sufridas por las industrias en España con motivo del actual estado de guerra, Madrid. Lecuona, Manuel y Manuel Martínez Torán (1998) «Encant i procés modernitzador del moble corbat», 
El modernisme a la Comunitat Valenciana, València: Diputació de València, Centre Cultural La Beneficència, 155-181.

Ley 4/1998, de 11 de junio, del Patrimonio Cultural Valenciano: DOGV núm. 3267, de 18/06/1998, (вОE núm. 174, de 22/07/1998).

Martínez Ferrando, Enrique (1953) «El Mueble Curvado», Cuatro Industrias Valencianas de abolengo, (reedición del libro de 1933), Valencia: Cámara de Comercio, Industria y Navegación de Valencia.

Mecedoras Modernistas. Disponible en https://www. youtube.com/watch?v=-qZS6lyCdUM [Fecha de consulta 04/01/2021]

Moble corbat de Viena $i$ de València (2019) Catàleg de l'Exposició al Museu de la Ciutat de Benicarló (MUCBE), juliol-setembre de 2019. Disponible en https://www.ajuntamentdebenicarlo.org/r2h/ files/24262.pdf [Fecha de consulta 04/01/2021]

Película viviente sobre la fábrica de muebles curvados Hijo de Ventura Feliu, Valencia (1929). Barcelona: Trilla. Disponible en https://www.youtube. com/watch?v=D0KI_JBdTFA_[Fecha de consulta 04/01/2021]
Real Sociedad Económica de Amigos del País (1883) Álbum de la Exposición Regional de Agricultura, Industria y Artes, Valencia, reimpresión de 1992.

RenzI, Chiara Carafa; RenzI, Giovanni y Wolfgang Thillmann (2006) Sedie a dondolo Thonet-Thonet Rocking Chairs, Milano: Silvana Editoriale.

Soler y MArco, Vicent (1984) Guerra i expansió industrial: País Valencià (1914-1923),Valencia: Alfons el Magnànim.

Torrent, Rosalía y Joan M. Marín (2005) Historia del diseño industrial, Madrid: Cátedra.

VAlENTí, A. (1911) «La industria de muebles curvados. Cómo se construye una mecedora», Por esos mundos, 1050-1053.

Recibido el 20 del 7 de 2021

Aceptado el 4 del 11 de 2021

BIBLID [2530-1330 (2021): 112-129]

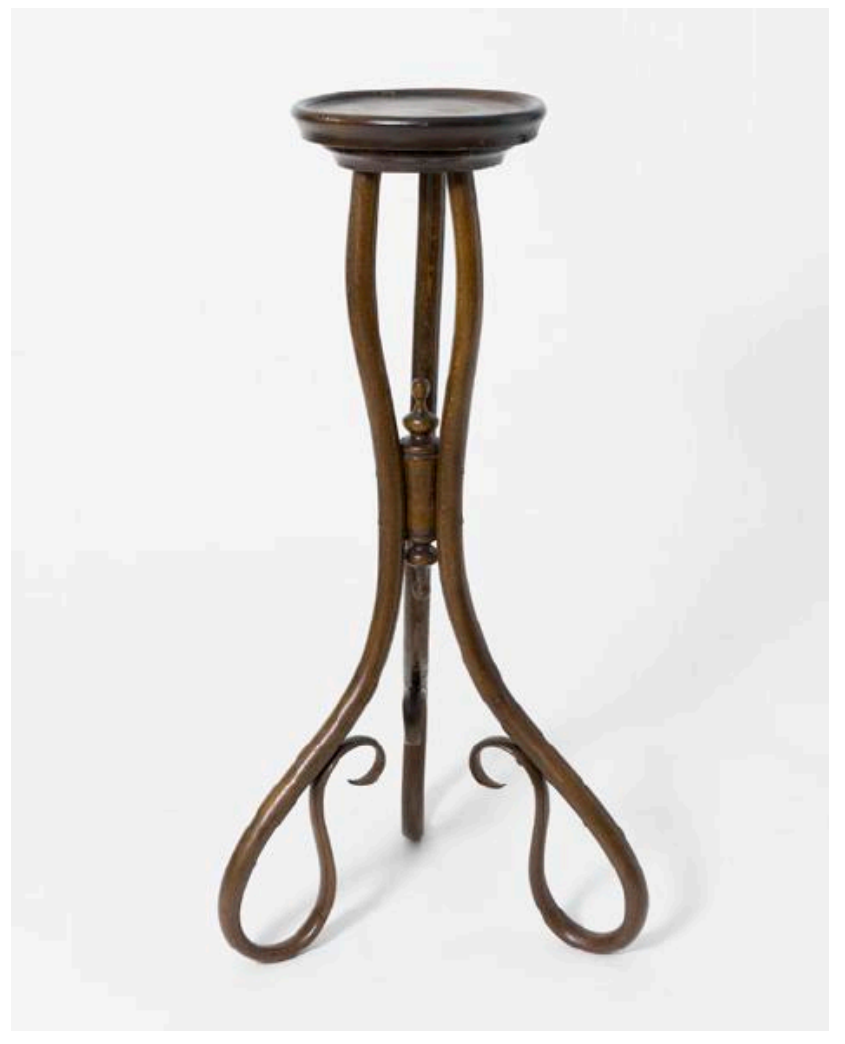

Jardinera de Hijos de Ventura Feliu. Fotografía: Luis Vives Chillida. 